\title{
Pengaruh Model PBT terhadap Kemampuan Berpikir Kritis dan Kemampuan Berpikir Kreatif Siswa SMA
}

\author{
Marike Muskitta $^{1}{ }^{*}$, Djukri $^{2}$ \\ ${ }^{1}$ Universitas Pattimura. Jalan Ir. M. Putuhena, Kampus Poka, Ambon, Maluku, Indonesia \\ ${ }^{2}$ Program Studi Pendidikan Biologi, Universitas Negeri Yogyakarta. Jalan Colombo No. 1, \\ Karangmalang, Yogyakarta 55281, Indonesia \\ * Korespondensi Penulis. Email: godfrey10ervanthe@gmail.com
}

\begin{abstract}
Abstrak
Penelitian ini bertujuan untuk mengetahui pengaruh model pembelajaran berdasarkan masalah terhadap kemampuan berpikir kritis dan pengaruh model pembelajaran berdasarkan masalah terhadap kemampuan berpikir kreatif siswa pada materi pencemaran lingkungan. Penelitian ini dilaksanakan di SMA Negeri 2 Magelang. Metode penelitian yang digunakan adalah kuasi eksperimen dengan desain nonrandomized control group pretest-posttest. Analisis data menggunakan uji t. Hasil perhitungan perbedaan rata-rata posttest pada kedua kelompok untuk kemampuan berpikir kritis menunjukkan nilai hitung sebesar 2,45 dan $\mathrm{t}_{\text {tabel }}$ dengan signifikasi $0,05 \%$ dengan $\mathrm{dk} 62=2,00$ sedangkan untuk kemampuan berpikir kreatif menunjukkan nilai hitung sebesar 3,43 dan $\mathrm{t}_{\text {tabel }}$ dengan signifikansi $0,05 \%$ dengan dk $62=2,00$. Hasil perhitungan tersebut menunjukkan bahwa $t_{\text {hitung }}>t_{\text {tabel }}$. Hal ini berarti hipotesis alternatif $(\mathrm{Ha})$ diterima dan hipotesis nol $\left(\mathrm{H}_{0}\right)$ ditolak. Dengan demikian, terdapat pengaruh penggunaan model pembelajaran berdasarkan masalah terhadap kemampuan berpikir kritis dan terdapat pengaruh model Pembelajaran Berdasarkan Masalah terhadap kemampuan berpikir kreatif siswa pada konsep pencemaran lingkungan.
\end{abstract}

Kata Kunci: penggunaan model pembelajaran berdasarkan masalah, kemampuan berpikir kritis dan kemampuan berpikir kreatif.

\section{The Effect of the Problem-Based Teaching Model on the Critical Thinking Skills and Creative Thinking Skills of the Students of SMA}

\begin{abstract}
This study aimed to determine the effect of the use of problem-based teaching model on the critical thinking skills and effect of the use of problem-based teaching model on the creative thinking skills of students on environmental pollution materials. The research was conducted at SMAN 2 Magelang. The research method used was a quasi-experimental design with nonrandomized control group pretest-posttest. The data analysis used the $t$ test. The result of the calculation of the posttest average of the difference between the two groups for critical thinking skills shows the calculated value of 2.45 and table with the significance level of $0.05 \%$ with $62 \mathrm{df}=2.00$, while for the ability to think creatively the calculated value of 3.43 shows the $t_{\text {table }}$ with the significance level of $0.05 \%$ with $62 d f=$ 2.00. This shows that $t>t_{\text {table. }}$. This means that the alternative hypothesis $(\mathrm{Ha})$ is accepted and null hypothesis $\left(H_{0}\right)$ is rejected. Thus, there is an effect of the use of problem-based teaching model on the critical and creative thinking skills of the students on the concept of environmental pollution.
\end{abstract}

Keywords: use of problem-based teaching model, critical and creative thinking skills.

How to Cite: Muskitta, M., \& Djukri, D. (2016). Pengaruh model PBT terhadap kemampuan berpikir kritis dan kemampuan berpikir kreatif siswa SMAN 2 Magelang. Jurnal Inovasi Pendidikan IPA, 2(1), 58-65. doi:http://dx.doi.org/10.21831/jipi.v2i1.8809

Permalink/DOI: http://dx.doi.org/10.21831/jipi.v2i1.8809 


\section{PENDAHULUAN}

Pada era informasi dan komunikasi, Indonesia memerlukan sumber daya manusia yang kreatif dan terampil untuk menghasilkan karya inovatif. Oleh karena itu, kurikulum pendidikan Sekolah Menengah Atas (SMA) menekankan pada bagaimana memfasilitasi belajar peserta didik untuk berpikir kreatif agar memiliki kompetensi untuk bekerja sama, memahami potensi diri, meningkatkan kinerja dan berkomunikasi secara efektif dalam setiap pemecahan masalah yang dihadapi. Dengan demikian, pembelajaran di SMA tidak hanya bertujuan untuk pemahaman pengetahuan saja, tetapi juga kemampuan untuk memecahkan permasalahan yang kompleks dalam kehidupan.

Kemampuan berpikir tingkat tinggi atau high order thinking skill sangat perlu dimiliki oleh peserta didik khususnya peserta didik di SMA. Berpikir dalam tingkat yang lebih tinggi dan dalam konteks yang benar mengajarkan kepada mereka kebiasaan berpikir mendalam, kebiasaan menjalani hidup dengan pendekatan yang cerdas, seimbang, dan dapat dipertanggungjawabkan. Dengan demikian, peserta didik mampu menghadapi dan memecahkan masalah atau isu-isu dalam kehidupan sehari-hari yang semakin hari semakin kompleks sesuai dengan kemajuan ilmu pengetahuan dan teknologi berdasarkan pengalaman mereka karena belajar adalah sesuatu yang terjadi sebagai hasil atau akibat dari pengalaman dan mendahului perubahan perilaku (Hargenhahn \& Olson, 2010, p. 4).

Pengertian berpikir adalah keterampilan mental yang memadukan kecerdasan dengan pengalaman. Banyak orang yang sangat cerdas berpegang pada suatu pendapat tentang subjek tertentu kemudian menggunakan kecerdasan mereka untuk mempertahankan pendapat tersebut (Bono, 2007, p.24).

Menurut Arends (2008, p.43), berpikir adalah suatu proses yang melibatkan operasioperasi mental (seperti: induksi, deduksi, klasifikasi, dan penalaran) untuk merepresentasikan secara simbolis (melalui bahasa) berbagai objek dan kejadian riil dan menggunakan representatif simbolis itu untuk menemukan prinsip-prinsip esensial objek dan kejadian tersebut.

Representasi simbolis (abstrak) itu biasanya dibandingkan dengan operasi mental yang di dasarkan pada fakta dan kasus-kasus tertentu di tingkat konkret. Sementara itu, berpikir tingkat tinggi merupakan merupakan suatu kerja keras, cenderung bersifat kompleks, melibatkan pertimbangan, penerapan banyak kriteria, melibatkan pencarian makna dan seringkali menghasilkan banyak solusi.

Berbasis pernyataan-pernyataan paling komtemporer tentang berpikir yang menyatakan bahwa higher-level thinking skills (keterampilan berpikir tingkat tinggi) tidak sama dengan keterampilan-keterampilan yang berhubungan dengan pola-pola perilaku yang lebih rutin, maka keterampilan berpikir tingkat tinggi tidak dapat diajarkan dengan menggunakan pendekatan-pendekatan yang dirancang untuk mengajarkan ide-ide dan keterampilan-keterampilan konkret. Hal ini sesuai dan searah dengan pendapat Ramizes \& Ganaden (2008, p.23) yang menyatakan bahwa "Higher order thinking skills, using creative activities in classroom instruction" yaitu keterampilan berpikir tingkat tinggi memerlukan keterampilan yang kreatif di kelas.

Brookhart (2010, p.3) mendefiniskan berpikir tingkat tinggi ke dalam istilah transfer, berpikir kritis dan problem solving atau pemecahan masalah. Berpikir tingkat tinggi dalam istilah transfer adalah suatu proses pembelajaran dimana peserta didik tidak hanya sekedar mampu mengingat materi pelajaran tetapi juga peserta didik mampu mengaplikasikan materi pelajaran dalam kehidupan sehari-hari. Dalam hal ini termasuk ke dalam pembelajaran bermakna atau meaningfull learning.

Thomas, Thorne \& Small (2000, p.3) mendefenisikan berpikir tingkat tinggi sebagai berikut: Higher order thinking is thinking on a higher level than memorizing facst or telling something back to someone exactly the way the it was told to you. When a person memorizes and gives back the infor-mation without having to think about it, we call it rote memory. Berdasarkan pada pernyataan tersebut, dapat dijelaskan bahwa berpikir pada tingkat adalah berpikir pada tingkat yang lebih tinggi, dari pada mengingkat suatu fakta atau mengatakan sesuatu kepada seseorang sama seperti yang diberitahukan kepadanya. Ketika seseorang menghafal dan memberikan kembali informasi tanpa berpikir tentang hal ini, kita menyebutnya memori hafalan.

Berpikir tingkat tinggi merupakan kemampuan berpikir pada tingkat yang lebih tinggi dari mengingat atau menghafal suatu konsep materi pelajaran. Peserta didik perlu memiliki kemampuan berpikir tingkat tinggi dalam menghadapi isu-isu di sekelilingnya sehingga peserta didik tidak hanya bertindak sebagai penonton 
tapi juga ikut terlibat dalam pemecahan isu-isu tersebut. Hal ini sejalan dengan pendapat Lyn (2013, p.49) yang menyatakan bahwa "Higher order thinking basically means thinking that is taking place in the higher-levels of the hierarchy of cognitive processing" yaitu berpikir tingkat tinggi adalah berpikir yang lebih dari sekedar proses kognitif.

Johnson (2009, p.182) menyatakan bahwa berpikir tingkat tinggi mengarah kepada dua hal, yaitu berpikir kritis dan berpikir kreatif. Berpikir kritis merupakan sebuah proses yang terarah dan jelas yang digunakan dalam kegiatan mental, seperti memecahkan masalah, mengambil keputusan, menganalisis asumsi, melakukan penelitian ilmiah dan dapat melatih peserta didik agar memiliki kemampuan untuk berpendapat dengan cara yang terorganisasi serta dapat mengevaluasi secara sistematis nilai pendapat pribadi dan pendapat orang lain.

Berpikir tingkat tinggi dalam istilah berpikir kreatif adalah sebuah kebiasaan dari pikiran yang dilatih dengan memperhatikan intuisi, menghidupkan imajinasi, mengungkapkan kemungkinan-kemungkinan baru, membuka sudut pandang yang menakjubkan, dan membangkitkan ide-ide yang tidak terduga serta kegiatan mental yang memupuk ide-ide asli dan pemahaman-pemahaman baru.

Hal ini sesuai dengan tujuan pembelajaran sains diantaranya melakukan inkuiri ilmiah untuk menumbuhkan kemampuan berpikir tingkat tinggi peserta didik yang meliputi kemampuan berpikir kritis dan kreatif. Proses pembelajaran Biologi sekarang ini mengarahkan peserta didik hanya untuk mempelajari sains sebagai produk, menghafalkan konsep, teori, dan hukum. Keadaan ini dipengaruhi oleh pembelajaran yang berorientasi pada tes atau ujian. Akibatnya sains sebagai proses, sikap dan aplikasi belum maksimal diterapkan dalam pembelajaran untuk meningkatkan kemampuan berpikir peserta didik. Proses pembelajaran yang diterapkan saat ini, belum menyentuh domain kognitif dan psikomotor dari peserta didik. Keadaan ini sangat berbanding terbalik dengan tujuan pembelajaran sains, yaitu melakukan inkuiri ilmiah untuk menumbuhkan kemampuan berpikir tingkat tinggi peserta didik yang meliputi kemampuan berpikir kritis dan kreatif.

Berdasarkan Peraturan Pemerintah No. 22 Tahun 2006 tentang Standar Isi untuk jenjang Pendidikan Dasar dan Menengah, pengembangan kemampuan berpikir tingkat tinggi merupakan salah satu tujuan mata pelajaran Biologi.
Biologi sebagai salah satu mata pelajaran sains di SMA mempelajari topik-topik yang mengandung isu atau permasalahan dalam kehidupan sehari-hari. Dalam mempelajari Biologi, peserta didik diharapkan tidak hanya menguasai Biologi sebagai produk yang berupa pengetahuan, tetapi juga mampu menguasai Biologi sebagai sikap, proses, aplikasi, dan kreativitas untuk dapat memecahkan permasalahan kehidupan sehari-hari secara kontekstual.

Oleh karena itu, peserta didik diharapkan mampu mengembangkan kemampuan berpikir analitis, induktif, dan deduktif dengan menggunakan konsep dan prinsip biologi dan memiliki kemampuan berpikir tingkat tinggi atau high order thinking skill. Heong, Othman, Yunos, Kiong, Hassan, \& Mohamad (2011, p.121) menyatakan bahwa "higher order thinking skills is an important aspect in teaching and learning" yaitu berpikir tingkat tinggi sangat penting dalam proses pembelajaran. Masih banyak peserta didik di tingkat SMA yang cerdas, pintar, dan berpengetahuan luas, namun belum mampu berpikir secara kritis, kreatif, dan inovatif dalam menghadapi suatu permasalahan baik itu menyangkut masalah sains, sosial, maupun humaniora di sekolah dan masyarakat.

Hal ini terjadi, karena di dalam proses pembelajaran yang berlangsung di sekolah masih mengarah pada pengungkapan masalah di lapisan atas (supervisial), artinya para guru dalam menyampaikan informasi ilmu pengetahuan dan teknologi kepada peserta didik terlalu banyak menggunakan alat ukur penilaian tentang apa (what) saja masalah yang terjadi, tetapi sedikit sekali menggunakan alat ukur penilaian tentang mengapa (why) masalah itu terjadi.

Pemilihan model pembelajaran merupakan hal yang sangat penting yang perlu diperhatikan untuk menumbuhkan keterampilan berpikir peserta didik secara lebih baik. Salah satu model pembelajaran yang dapat diterapkan dalam pembelajaran Biologi adalah model problem based teaching, karena model pembelajaran ini berpusat pada peserta didik atau menempatkan peserta didik sebagai subjek belajar sehingga peserta didik lebih mudah menemukan dan memahami konsep-konsep yang sulit dengan mendiskusikannya dengan peserta didik lainnya dan dapat mendorong terciptanya budaya berpikir kritis dan kreatif pada peserta didik.

Model problem based teaching merupakan suatu model pembelajaran yang didasarkan pada banyaknya permasalahan yang membutuhkan penyelidikan autentik, yaitu penyelidikan 
yang membutuhkan penyelesaian nyata dari permasalahan yang nyata. Dari contoh permasalahan yang nyata, memungkinkan peserta didik memahami konsep dan bukan sekedar menghafal konsep. Menurut Graaff \& Kolmos (2003, p.657) "defines the concept interms of specific attributes as being student centered, taking place in small groups with the teacher acting as a facilitators" yaitu mendefenisikan suatu konsep pembelajaran yang berpusat pada peserta didik yang dilakukan dalam suatu kelompok kecil dan guru hanya bertindak sebagai fasilitator.

Menurut Awang \& Ramly (2008, p.18) menyatakan bahwa "Problem Based Teaching is a total pedagogical approach to education that focuces on helping student develop self directed learning skills" yaitu merupakan suatu pendekatan pedagogik yang berfungsi untuk membantu peserta didik mengembangkan dirinya yang diarahkan pada suatu keterampilan belajar. Peserta didik dapat berusaha sendiri untuk mencari pemecahan masalah serta pengetahuan yang berdasarkan pengalaman yang konkrit dan dengan pengalaman tersebut dapat memberikan makna tersendiri bagi peserta didik.

Menurut Dewey (Trianto, 2010, p.90), belajar berdasarkan masalah adalah interaksi antara stimulus dengan respons dan merupakan hubungan antara dua arah yaitu belajar dan lingkungan. Lingkungan memberi masukan kepada peserta didik berupa bantuan dan masalah, sedangkan sistem saraf otak berfungsi menafsirkan bantuan itu secara efektif sehingga masalah yang dihadapi dapat diselidiki, dinilai dan dianalisis serta dicari pemecahannya yang baik.

Ciri-ciri utama Problem Based Teaching adalah meliputi suatu pengajuan pertanyaan atau masalah, memusatkan keterkaitan antar disiplin, penyelidikan autentik, kerja sama, dan menghasilkan karya serta peragaan dan tidak dirancang untuk membantu guru memberikan informasi sebanyak-banyaknya kepada peserta didik. Berdasarkan karakter tersebut, pembelajaran berdasarkan masalah memiliki tujuan sebagai berikut: (a). Membantu peserta didik mengembangkan keterampilan berpikir dan keterampilan pemecahan masalah, (b). Belajar peranan orang dewasa yang autentik, (c). Menjadi pelajar yang mandiri (Trianto, 2010, p.90).

Selain tujuannya, adapun manfaat yang dapat diperoleh dari model Problem Based Teaching yaitu dikembangkan untuk membantu peserta didik mengembangkan kemampuan berpikir, pemecahan masalah, dan keterampilan intelektual, dapat berperan untuk berbagai peran orang dewasa melalui keterlibatan mereka dalam pengalaman nyata. Ada juga manfaat lain dari model Problem Based Teaching yaitu: (a) menjadi lebih giat dan meningkat pemahamannya atas materi ajar, (b) meningkatkan fokus pada penelitian yang relevan, (c) mendorong untuk berpikir, (d) membangun kerja tim, kepemimpinan, dan keterampilan sosial, (e) membangun kecakapan belajar, dan f) memotivasi pemelajar (Amir, 2009,p.27).

Pengalaman peserta didik yang diperoleh dari lingkungan menjadikan kepadanya bahan dan materi guna memperoleh pengertian serta dapat dijadikan pedoman dari tujuan belajarnya. Problem based teaching juga merupakan pendekatan yang efektif untuk pengajaran proses berpikir tingkat tinggi. Pembelajaran ini membantu peserta didik untuk memproses informasi yang sudah ada dalam benaknya dan menyusun pengetahuan mereka sendiri tentang dunia sosial dan sekitarnya dan pembelajaran ini cocok untuk mengembangkan pengetahuan dasar maupun kompleks. Huang (2005, p.37) menyatakan bahwa "Learning emphasis on perception of the concrete idea" yaitu proses pembelajaran dengan model problem based teaching lebih mengarah pada suatu hal yang konkret. Merupakan sesuatu yang menarik untuk mengetahui Pengaruh Penerapan model Problem Based Teaching terhadap Kemampuan Berpikir kritis dan Kemampuan Berpikir Kreatif di SMA Negeri 2 Kota Magelang. Penelitian ini bertujuan untuk menguji ada atau tidaknya pengaruh model problem based teaching terhadap kemampuan berpikir kritis dan kemampuan berpikir kreatif peserta didik di SMA Negeri 2 Magelang.

\section{METODE}

\section{Jenis Penelitian}

Jenis penelitian yang digunakan adalah eksperimen semu (quasi experimental). Desain ini menggunakan dua kelas perlakuan. Pada kelas eksperimen diberikan perlakuan dengan penerapan model problem based teaching, sedangkan pada kelas kontrol pembelajaran menggunakan model pembelajaran biasa yang diterapkan disekolah.

\section{Tempat dan Waktu Penelitian}

Penelitian dilaksanakan di SMA Negeri 2 Magelang, jalan Urip Soemoharjo. Penelitian 
dimulai dari tanggal 13 Maret sampai dengan 25 April 2013.

\section{Populasi dan Sampel Penelitian}

Populasi dalam penelitian ini adalah seluruh siswa kelas X SMA Negeri 2 Magelang yang terdiri atas 7 kelas dengan jumlah 224 orang. Teknik pengambilan sampel pada penelitian ini adalah dengan purposive sampling sehingga diperoleh kelas Xa sebagai kelas kontrol dan kelas $\mathrm{Xb}$ sebanyak masing-masing 32 orang sebagai kelas eksperimen.

\section{Prosedur}

Langkah-langkah yang dilakukan dalam penelitian eksperimen berupa: (1) memberikan pretest pada kedua kelompok; (2) melakukan perlakuan dengan menerapkan model problem based teaching pada kelas eksperimen dan model pembelajaran biasa pada kelas kontrol; (3) memberikan posstest pada kedua kelompok. Desain penelitian menggunakan nonrandomized control group pretest-posstest design.

\section{Data, Instrumen dan Teknik Pengumpulan Data}

Data dalam penelitian ini adalah hasil tes kemampuan berpikir kritis dan kemampuan berpikir kreatif. Data dikumpulkan dengan teknik pretest dan posttest. Instrumen yang digunakan dalam penelitian ini yaitu instrumen tes berbentuk uraian untuk mengukur kemampuan berpikir kritis dan kreatif peserta didik.

\section{Teknik Analisis Data}

Data hasil tes kemampuan berpikir kritis dan kemampuan berpikir kreatif dianalisis dengan mengunakan uji t.

$$
\begin{aligned}
& t=\frac{\bar{X}_{1}-\bar{X}_{2}}{s \sqrt{\frac{1}{n_{1}}+\frac{1}{n_{2}}}} \text { dimana } S^{2} \\
& =\frac{(n 1-1) S_{1}{ }^{2-\left(n_{2}-1\right) s_{2}}{ }^{2}}{n_{1}+n_{2}-2}, d b=n_{1}+n_{2-2}
\end{aligned}
$$

dimana:

$\bar{X}_{1}=$ Mean atau rata-rata kelas eksperimen

$\bar{X}_{2}=$ Mean atau rata-rata kelas kontrol

$S_{1^{2}}=$ Variansi kelas eksperimen

$S_{2^{2}}=$ Variansi kelas kontrol

$n_{1}=$ Jumlah peserta didik kelas eksperimen

$n_{2}=$ Jumlah peserta didik kelas kontrol

$\mathrm{S}=$ Simpangan baku gabungan

$\mathrm{t}=$ Nilai $\mathrm{t}$-tes yang dicari

Adapun kriteria pengujian untuk uji $t$ ini adalah sebagai berikut:
$\mathrm{H}_{0}$ diterima apabila $\mathrm{t}_{\text {hitung }}<\mathrm{t}_{\text {tabel }}$

$\mathrm{H}_{0}$ ditolak apabila $\mathrm{t}_{\text {hitung }} \geq \mathrm{t}_{\text {tabel }}$

\section{HASIL DAN PEMBAHASAN}

\section{Hasil Penelitian}

Hasil tes kemampuan berpikir kritis siswa pada kedua kelompok sebelum diberikan perlakuan disajikan pada tabel 1.

Tabel 1. Uji Hipotesis Hasil Pretest Kemampuan Berpikir Kritis

\begin{tabular}{ccc}
\hline Keterangan & Kelas Eksperimen & Kelas Kontrol \\
\hline Sampel & 32 & 32 \\
Rata-rata & 28,84 & 29,81 \\
$\mathrm{~S}^{2}$ & 81,83 & 71,74 \\
$\mathrm{t}_{\text {hitung }}$ & \multicolumn{2}{c}{0,501} \\
$\mathrm{t}_{\text {tabel }}$ & \multicolumn{2}{c}{2,00} \\
Kesimpulan & $\mathrm{H}_{0}$ diterima, $\mathrm{H}_{2}$ ditolak
\end{tabular}

Dari hasil perhitungan nilai $t_{\text {hitung }} 0,501$ dan $t_{\text {tabel }} 2,00$ menunjukkan bahwa $t_{\text {hitung }}<t_{\text {tabel }}$ $(0,501<2,00)$, hal ini berarti bahwa pada taraf signifikansi $0,05 \mathrm{H}$ diterima dan Ha ditolak serta tidak terdapat perbedaan antara kelas eksperimen dan kelas kontrol, maka dapat disimpulkan bahwa terdapat perbedaan kemampuan terdapat kemampuan berpikir kritis yang sama antara kelas eksperimen dan kelas kontrol.

Hasil tes kemampuan berpikir kritis siswa pada kedua kelompok setelah diberikan perlakuan disajikan pada Tabel 2.

Tabel 2. Uji Hipotesis Hasil Posstest Kemampuan Berpikir Kritis.

\begin{tabular}{ccc}
\hline Keterangan & $\begin{array}{c}\text { Kelas } \\
\text { Eksperimen }\end{array}$ & $\begin{array}{c}\text { Kelas } \\
\text { Kontrol }\end{array}$ \\
\hline Sampel & 32 & 32 \\
Rata-rata & 60,09 & 53,75 \\
$\mathrm{~S}^{2}$ & 307,97 & 224,34 \\
$\mathrm{t}_{\text {hitung }}$ & \multicolumn{2}{c}{2,45} \\
$\mathrm{t}_{\text {tabel }}$ & \multicolumn{2}{c}{2,00} \\
Kesimpulan & $\mathrm{H}_{0}$ ditolak, $\mathrm{H}_{\mathrm{a}}$ diterima \\
\hline
\end{tabular}

Dari hasil perhitungan nilai $\mathrm{t}_{\text {hitung }} 2,45$ dan $t_{\text {tabel }} 2,00$ menunjukkan bahwa $t_{\text {hitung }}>t_{\text {tabel }}(2,45$ $>2,00$ ), hal ini berarti bahwa pada taraf signifikansi $0,05 \mathrm{H}_{0}$ ditolak dan $\mathrm{H}_{\mathrm{a}}$ diterisma. Dengan demikian menunjukkan bahwa terdapat pengaruh yang signifikan penerapan model problem based teaching terhadap kemampuan berpikir kritis peserta didik.

Hasil tes kemampuan berpikir kreatif siswa pada kedua kelompok sebelum diberikan perlakuan disajikan pada Tabel 3 . 
Tabel 3. Uji Hipotesis Hasil Pretest Kemampuan Berpikir Kreatif

\begin{tabular}{ccc}
\hline Keterangan & Kelas Eksperimen & Kelas Kontrol \\
\hline Sampel & 32 & 32 \\
Rata-rata & 30,5 & 37,5 \\
$\mathrm{~S}^{2}$ & 99,87 & 68,38 \\
$\mathrm{t}_{\text {hitung }}$ & \multicolumn{2}{c}{1,67} \\
$\mathrm{t}_{\text {tabel }}$ & \multicolumn{2}{c}{2,00} \\
Kesimpulan & $\mathrm{H}_{0}$ diterima, $\mathrm{H}_{\mathrm{a}}$ ditolak \\
\hline
\end{tabular}

Dari hasil perhitungan nilai $\mathrm{t}_{\text {hitung }} 1,67$ dan $\mathrm{t}_{\text {tabel }} 2,00$ menunjukkan bahwa $\mathrm{t}_{\text {hitung }}<\mathrm{t}_{\text {tabel }}(1,67$ $<2,00$ ), hal ini berarti bahwa pada taraf signifikansi $0,05 \quad \mathrm{H}_{0}$ diterima dan $\mathrm{H}_{\mathrm{a}}$ ditolak serta tidak terdapat perbedaan antara kelas eksperimen dan kelas kontrol, maka dapat disimpulkan bahwa terdapat perbedaan kemampuan terdapat kemampuan berpikir kritis yang sama antara kelas eksperimen dan kelas kontrol.

Hasil tes kemampuan berpikir kritis siswa pada kedua kelompok setelah diberikan perlakuan disajikan pada Tabel 4.

Tabel 4. Uji Hipotesis Hasil Posstest Kemampuan Berpikir Kreatif

\begin{tabular}{|c|c|c|}
\hline Keterangan & Kelas Eksperimen & Kelas Kontrol \\
\hline Sampel & 32 & 32 \\
\hline Rata-rata & 41,125 & 36 \\
\hline$S^{2}$ & 52,38 & 39,53 \\
\hline$t_{\text {hitung }}$ & \multicolumn{2}{|c|}{3,43} \\
\hline $\mathrm{t}_{\text {tabel }}$ & \multicolumn{2}{|c|}{2,00} \\
\hline
\end{tabular}

Dari hasil perhitungan nilai $\mathrm{t}_{\text {hitung }} 3,43$ dan $\mathrm{t}_{\text {tabel }} 2,00$ menunjukkan bahwa $\mathrm{t}_{\text {hitung }}>\mathrm{t}_{\text {tabel }}(3,43$ $>2,00$ ), hal ini berarti bahwa pada taraf signifikansi $0,05 \mathrm{H}_{0}$ ditolak dan $\mathrm{H}_{\mathrm{a}}$ diterima. Dengan demikian menunjukkan bahwa terdapat pengaruh yang signifikan penerapan Model problem based teaching terhadap kemampuan berpikir kreatif peserta didik.

\section{Pembahasan}

Pembelajaran dilaksanakan pada kedua kelas yang menjadi sampel penelitian, yaitu kelas Xa sebagai kelas kontrol dengan menggunakan model pembelajaran yang biasanya dilakukan di sekolah, sedangkan kelas Xb sebagai kelas eksperimen dengan penerapan model Problem Based Teaching.

Uji normalitas dilakukan untuk mengetahui apakah data yang diperoleh berasal dari subjek penelitian berdistribusi normal ataukah tidak, dan dilakukan dengan menggunakan uji Liliefors. Kriteria uji normalitas adalah $\mathrm{H} 0$ diterima jika Lhitung $<$ Ltabel dan H0 ditolak jika Lhitung $>$ Ltabel. Dengan diterimanya HO ber- arti data tersebut berasal dari populasi berdistribusi normal, sedangkan jika H0 ditolak berarti data tersebut berasal dari populasi berdistribusi tidak normal.

Berdasarkan hasil pengujian uji normalitas yang telah dilakukan terhadap kemampuan berpikir kritis, diperoleh hasil uji normalitas pretest kelas eksperimen dengan Lhitung sebesar 0,127133 dan kelas kontrol sebesar 0,1374889 serta posttest kelas eksperimen diperoleh L hitung sebesar 0,142322 dan kelas kontrol sebesar 0,132344 yang kemudian dibandingkan dengan Ltabel 1,58214 maka dapat katakan bahwa L hitung < L tabel sehingga kedua kelas ini berdistribusi normal karena Lhitung kurang dari Ltabel.

Untuk kemampuan berpikir kreatif diperoleh hasil uji normalitas pretest kelas eksperimen dengan Lhitung sebesar 0,109411 dan kelas kontrol sebesar 0,013931 sedangkan posttest kelas eksperimen diperoleh Lhitung sebesar 0,139022 dan kelas kontrol sebesar 0,127333 yang kemudian dibandingkan dengan Ltabel 1,58214 yang berarti Lhitung < Ltabel sehingga dapat katakan bahwa kedua kelas ini berdistribusi normal karena Lhitung kurang dari Ltabel.

Uji homogenitas atau uji kesamaan dua varians populasi pada penelitian ini dilakukan dengan menggunakan uji Fisher, dimana subjek penelitian dinyatakan homogen jika Fhitung < Ftabel yang diukur pada taraf signifikansi 0,05 .

Dari data uji homogenitas berpikir kritis digabungkan kedua data hasil pretest kelas eksperimen dan kelas kontrol diperoleh Fhitung sebesar 1,14 sedangkan posttest kelas eksperimen dan kelas kontrol diperoleh Fhitung sebesar 1,38 yang kemudian dibandingkan dengan Ftabel 1,74 yang berarti Fhitung < Ftabel maka dapat katakan bahwa kedua kelas ini memiliki varians yang homogen karena Fhitung kurang dari Ftabel.

Untuk uji homogenitas berpikir kreatif, digabungkan kedua data hasil pretest kelas eksperimen dan kelas kontrol diperoleh Fhitung sebesar 1,46 sedangkan posttest kelas eksperimen dan kelas kontrol diperoleh Fhitung sebesar 1,32 yang kemudian dibandingkan dengan Ftabel 1,74 yang berarti Fhitung < Ftabel maka dapat katakan bahwa kedua kelas ini memiliki varians yang homogen karena diperoleh hasil Fhitung kurang dari Ftabel. Setelah diperoleh hasil uji normalitas dan homogenitas, maka langkah selanjutnya adalah data hasil penelitian diuji dengan uji hipotesis. 
Uji hipotesis dilakukan terhadap data pretest dan posttest kedua kelas yang terbukti berdistribusi normal dan homogen dengan menggunakan uji t. Pengujian hipotesis pada data pretest dilakukan untuk mengetahui apakah kedua kelas tersebut mempunya nilai yang sama ataukah tidak sama (berbeda).

Pengujian hipotesis pada data posttest dilakukan untuk mengetahui apakah terdapat pengaruh yang signifikan dari penerapan model problem based teaching terhadap kemampuan berpikir kritis dan kemampuan berpikir kreatif peserta didik.

Adapun hasil uji hipotesis pretest kemampuan berpikir kritis untuk kelas eksperimen dan kelas kontrol diperoleh thitung sebesar 0,501 dengan ttabel sebesar 2,00 yang berarti bahwa thitung < ttabel sehingga dapat dikatakan bahwa tidak terdapat perbedaan kemampuan berpikir kritis dan kemampuan berpikir kreatif peserta didik sebelum diberikan perlakuan dengan model problem based teaching pada kelas eksperimen maupun kelas kontrol karena thitung kurang dari ttabel.

Untuk hasil uji hipotesis posttest kemampuan berpikir kritis untuk kelas eksperimen dan kelas kontrol diperoleh thitung sebesar 2,45 dengan ttabel sebesar 2,00 yang berarti bahwa thitung > ttabel ini menunjukkan bahwa terdapat perbedaan kemampuan berpikir kritis dan kemampuan berpikir kreatif peserta didik setelah diberikan perlakuan dengan penerapan model problem based teaching pada kelas eksperimen karena thitung lebih dari ttabel.

Hasil uji hipotesis pretest kemampuan berpikir kreatif untuk kelas eksperimen dan kelas kontrol diperoleh thitung sebesar 1,67 dengan ttabel sebesar 2,00 yang berarti bahwa thitung < ttabel sehingga dapat dikatakan bahwa tidak terdapat perbedaan kemampuan berpikir kritis dan kemampuan berpikir kreatif peserta didik sebelum diberikan perlakuan dengan penerapan model problem based teaching pada kelas eksperimen maupun kelas kontrol karena $t_{\text {hitung }}$ kurang dari $t_{\text {tabel. }}$.

Untuk hasil uji hipotesis posttest kemampuan berpikir kreatif untuk kelas eksperimen dan kelas kontrol diperoleh $t_{\text {hitung }}$ sebesar 3,43 dengan $t_{\text {tabel }}$ sebesar 2,00 yang berarti bahwa $t_{\text {hitung }}>t_{\text {tabel }}$ ini menunjukkan bahwa terdapat perbedaan kemampuan berpikir kritis dan kemampuan berpikir kreatif peserta didik setelah diberikan perlakuan dengan penerapan model problem based teaching pada kelas eksperimen karena $t_{\text {hitung }}$ lebih dari $t_{\text {tabel. }}$.

\section{SIMPULAN DAN SARAN}

\section{Simpulan}

Ada pengaruh yang signifikan penerapan model problem based teaching terhadap kemampuan berpikir kritis peserta didik pada materi pencemaran lingkungan yaitu dengan perhitungan uji $t$ diperoleh harga $t_{\text {hitung }}$ lebih besar dari $\mathrm{t}_{\text {tabel}}$, sehingga dapat disimpulkan bahwa penerapan model problem based teaching dapat meningkatkan kemampuan berpikir kritis peserta didik kelas X di SMA Negeri 2 Magelang.

Ada pengaruh yang signifikan penerapan model problem based teaching terhadap kemampuan berpikir kreatif peserta didik pada materi pencemaran lingkungan dengan perhitungan uji $\mathrm{t}$ diperoleh harga $t_{\text {hitung }}$ lebih besar dari $t_{\text {tabel }}$ sehingga dapat disimpulkan bahwa penerapan model problem based teaching dapat meningkatkan kemampuan berpikir kritis peserta didik kelas X di SMA Negeri 2 Magelang.

\section{Saran}

Penerapan model problem based teaching dalam pembelajaran Biologi merupakan salah satu cara yang dapat dipakai guru untuk meningkatkan kemampuan berpikir kritis dan kemampuan berpikir kreatif pserta didik.

Model problem based teaching dapat di terapkan pada semua mata pelajaran termasuk Biologi, namun guru perlu memperhatikan waktu untuk menghubungkan antara materi pelajaran dengan model yang digunakan sehingga pembelajaran yang dilakukan dapat meningkatkan kemampuan berpikir tingkat tinggi peserta didik.

\section{DAFTAR PUSTAKA}

Amir, T. M. (2009). Inovasi pendidikan melalui Problem Based Learning: Bagaimana pendidik memberdayakan pemelajar di era pengetahuan. Jakarta: Kencana Prenada Media Group.

Arends, R. I. (2008). Learning to teach. (Terjemahan Helly Prajitno Soetjipto \& Sri Mulyantini Soetjipto). New York: McGraw Companies, Inc. (Buku asli diterbitkan tahun 2007).

Awang, H., \& Ramly, I. (2008). Creative thinking skill approach through problembased learning: Pedagogy and practice in the engineering classroom. Vol.3, no. 2, PP 33-38. Diambil tanggal 17 Juni 2013 dari: $\quad$ http//www.ijjssh.org/journal/20H009.pdf.s 
Bono, E. D. (2007). Revolusi berpikir: Belajar berpikir canggih dan kreatif dalam memecahkan masalah dan memantik ideide baru. (Terjemahan Sitompul, Ida \& Fahmy Yamani). Bandung: Kaifa (Buku asli diterbitkan tahun 1993).

Brookhart, S. M. (2010). How to assess higherorder thinking skills in yours classroom. Virginia: ASCD Member Books.

Graaff \& Kolmos (2003: 657). Defines the concept interms of specific attributes as being student centered, taking place in small groups with the teacher acting as a facilitators. Vol.2, no. 7, pp. 22-26. Diambil tanggal 17 Juni 2013. dari: http//www.pbl.org/journal/20-H009.pdf.s

Hargenhahn, B.R., \& Olson, M.H. (2010). Theories of learning: Teori belajar edisi ketujuh. (Terjemahan Tri wibowo B.S). Jakarta: Kencana. (Buku asli diterbitkan tahun 2008).

Heong, Y.M., Othman, W. B., Yunos, J.B.M., Kiong, T.T., Hassan, R.B, \& Mohamad, M.M.B. (2011): The level of marzano higher order thinking skills among thecnical education student. Vol. I, No. 2, PP 21-25. Diambil tanggal 17 Juni 2013 dari: $\quad$ http//www.ijjssh.org/journal/20H009.pdf.

Huang, R. (2005). Chinese International Students'Perception of the ProblemBased Learning Experience. Vol.4, no. 2, PP 48-57. Diambil tanggal 18 Juni 2013 dari: http//www.pbl.pubs.aged/journal/20H009.pdf.

Johnson, E. B. (2009). Contextual teaching \& learning: Menjadikan kegiatan belajarmengajar mengasyikkan dan bermakna. (Terjemahan Ibnu Setiawan). California: Corwin Press, Inc. (Buku asli diterbitkan tahun 2002).

Lyn, J. (2013). Higher Order Thinking Skills and Academic Performance in Physic Of College Students: A Regression Analysis. Vol.II, no. 4, PP 48-57. Diambil tanggal 18 Juni 2013 dari: http//www.ijjssh.org/journal/20-H009.pdf.

Ramizes, R.P.B., \& Ganaden, M.S. (2008). College of education creative activities and students' higher order thinking skills. Education Quarterly Journal. Vol.II, no. 4, PP 48-57. Diambil tanggal 18 Juni 2013 dari: http//www.ijjssh.org/journal/20-H009.pdf.

Thomas, A., Thorne, G., \& Small, B. (2000). Higher order thinking is thinking on a higher level than memorizing facst or telling something back to someone exactly the way the it was told to you. Diambil tanggal 17 Juni 2013. dari: http//www.ijjssh.pbl/journal/20-H009.pdf.

Trianto. (2010). Mendesain model pembelajaran inovatif-progresif: konsep, landasan, dan implementasinya pada kurikulum tingkat satuan pendidikan (KTSP) (edisi ke-satu). Jakarta: Kencana Prenada Media Group. 